\title{
Electrodeposition of Transition Metal Composites on Mild Steel: Structural and Wear Behaviour
}

\author{
P.Sathyabalan, M.D.Puhazhendhi, K.R.Aranganayagam, R.Kannan
}

\begin{abstract}
Wear characteristics of the transition metal composite (TMC) coated mild steel are investigated. TMC coatings were performed using electrodeposition technique on mild steel. Different concentrations of transition metals were subjected to prepare the TMC's and studied. The structural and the micro structural studies of the composites coatings were studied through $X$-ray diffraction (XRD) and scanning electron microscopy (SEM), respectively. The elemental compositions of coated composites were evaluated using Energy dispersive $X$-ray diffraction (EDS) studies. Both the structural and micro structural characterizations confirmed the formation of composite coatings. Further, it is evident from the EDS analyses that TMC's are coated with the desired concentrations. In order to understand the wear resistance of coated mild steel, the specimen were subjected to load on pin-on-disc type wear tester. The effects of concentration of composite and thickness of the coating on wear resistance are discussed. The coating results in improving the wear resistance and hardness of the specimen.
\end{abstract} EDX

Keywords - Composite coating, Electrodeposition, Wear, XRD,

\section{INTRODUCTION}

Life of a product is directly controlled not only by material aspects but also, by technical boundaries enforced by environmental conditions. These boundaries impose limiting criteria to access the functional feasibility of the product. For centuries people have been working on to improve the life of a product. Components are deemed to be unfit once their surfaces have degraded. This limit may vary from the appearance of minor pitting or scoring marks in bearing surfaces to the removal of several millimeters of material from the bucket of an excavating tool. In moving a car the frictional losses account for $21.3 \%$ of the total loss [1]. Reducing the frictional losses will decrease the fuel consumption.

A number of approaches have been carried out to improve the products life. Chief among them are adding alloying elements, using composite materials [2], graded materials [3] and employing surface treatments [4]. Structural modification of service properties of material parts area is

Revised Manuscript Received on August 14, 2019.

P.Sathyabalan, Department of Mechanical Engineering, Kumaraguru College of Technology, Coimbatore, India. (E-mail: sathyabalan.p.mec@kct.ac.in)

M.D.Puhazhendhi, Department of Mechanical Engineering, Kumaraguru College of Technology, Coimbatore, India. (E-mail: puhazhendhi.16mcc@kct.ac.in)

K.R.Aranganayagam, Department of Chemistry, Kumaraguru College of Technology, Coimbatore, India. (E-mail aranganayagam.kr.sci@kct.ac.in)

R.Kannan, Department of Physics, Kumaraguru College of Technology, Coimbatore, India. (E-mail: kannan.r.sci@kct.ac.in) increased by depositing adherent tiny coatings of small and/or nano dimension on the surface of the material [5]. The deposition might either be to enhance aesthetics or to improve engineering properties [6][7]. The structural modification imparts new service properties to the materials [8][9]. Rejuvenating techniques also are capable of increasing worn parts to their original tolerances, therefore reducing waste and replacement costs.

Electrodeposition is one of the important process of plating a material over another. It is used for various applications such as wear resistance, corrosion resistance [10] and decorative appearance [11]. In addition to those classical plating applications, recent development of composites to new areas, like electro-catalysis, photoactive materials or energy storage, have also been determined. Due to simplicity, low cost and less time consuming, the electrodeposition technique is selected for this composite coating work. Most composite coatings contain micronsized particles, though there is growing interest within the codeposition of nano particles as a result of their increasing handiness [12]. Mild steel is widely used material in structural applications due to good performance and balanced properties of strength, plasticity and weldability. It is widely used in the fabrication of mechanical components and abrasive tools in the less strict situation. However, the steel is susceptible to pitting corrosion in the natural environment because of its low abrasive resistance and chemical stability. Compared to the steel, nickel has higher chemical stability, drawabilityand plasticity, which makes it much harder and more resistant to abrasion and corrosion as coating material [13]. There are many techniques available for coating on MS materials, with varying thickness from several microns to several millimeters [14][15].

The prime objective of the present investigation is on the effect of transition metals composites on the mild steel towards wear resistance and hardness.

\section{EXPERIMENT}

\section{A. Plating Sample Preparation}

Experimental mild steel samples were sheared into required size of $10 \mathrm{~mm}$ diameter and $32 \mathrm{~mm}$ length from a lengthy mild steel rod. The samples were cleaned from heavy oils and dirt using dilute sulphuric acid and acetone. 


\section{ELECTRODEPOSITION OF TRANSITION METAL COMPOSITES ON MILD STEEL: STRUCTURAL AND WEAR BEHAVIOUR}

Then samples were washed in distilled water and dried [16]. After the cleaning process, emery sheets and grinding/polishing machine were used to polish the specimen.Transition metal composites were prepared with five different stiochiometric ratio of plating substance were taken and prepared for electrodeposition.

\section{B. Plating Procedure}

The weight of the samples was taken and noted before the start-up of the plating process. The deposition parameters considered in the present investigation, varied at different levels to study their effects on the weight of composite deposited, were voltage and plating time. The parameters were considered in the following order: plating temperature is from $30^{\circ}$ to $45^{\circ} \mathrm{C}$ and current density is $60-75 \mathrm{~mA}$. A magnetic stirrer was used in the Watts bath at $550 \mathrm{rpm}$. The optimum plating time is 30 minutes.

\section{Preparation and Process of Electrodeposition}

All the metal precursors (Merck) are in Analar grade and used as such. Solvents and reagents were purified under standard procedures. The electroplating solutions were prepared with desired concentration in the $200 \mathrm{ml}$ beaker with doubly distilled water. The concentrations of electrolyte solution are listed in the Table 1 to 5 for the sample 1 to 5 . The schematic representation and electrode assembly of the electro deposition technique are shown in Fig. 1. Attempts were made to optimize the input conditions such as $\mathrm{pH}$, temperature, current density etc. After the successful completion of optimization, the input conditions (discussed in Section II B), were fixed for the composite coatings process [11].

TABLE I. Basic bath Compositions for Ni coating (Sample 1)

\begin{tabular}{|l|l|}
\hline $\begin{array}{l}\text { Concentration of } \\
\mathrm{NiSO}_{4} \cdot 6 \mathrm{H}_{2} \mathrm{O}\end{array}$ & $100 \mathrm{~g} / \mathrm{L}$ \\
\hline Boric acid & $20 \mathrm{~g} / \mathrm{L}$ \\
\hline
\end{tabular}

TABLE II. Basic bath Compositions for $\mathrm{Ni}+\mathrm{Zn}$ coating (Sample 2)

\begin{tabular}{|l|l|}
\hline $\begin{array}{l}\text { Concentration of } \\
\mathrm{NiSO}_{4} \cdot 6 \mathrm{H}_{2} \mathrm{O}\end{array}$ & $52 \mathrm{~g} / \mathrm{L}$ \\
\hline Zinc acetate dehydrate & $44 \mathrm{~g} / \mathrm{L}$ \\
\hline Boric acid & $10 \mathrm{~g} / \mathrm{L}$ \\
\hline
\end{tabular}

TABLE III. Basic bath Compositions for $\mathrm{Ni}+\mathrm{Mn}$ coating (Sample 3)

\begin{tabular}{|l|l|}
\hline $\begin{array}{l}\text { Concentration of } \mathrm{NiSO}_{4} \cdot \\
6 \mathrm{H}_{2} \mathrm{O}\end{array}$ & $52 \mathrm{~g} / \mathrm{L}$ \\
\hline $\begin{array}{l}\text { Concentration of } \mathrm{MnSO}_{4} \cdot \\
6 \mathrm{H}_{2} \mathrm{O}\end{array}$ & $34 \mathrm{~g} / \mathrm{L}$ \\
\hline Boric acid & $10 \mathrm{~g} / \mathrm{L}$ \\
\hline
\end{tabular}

TABLE IV. Basic bath Compositions for $\mathrm{Zn}+\mathrm{Mn}$ coating(Sample 4)

\begin{tabular}{|l|l|}
\hline Zinc acetate dehydrate & $44 \mathrm{~g} / \mathrm{L}$ \\
\hline $\begin{array}{l}\text { Concentration of } \\
\mathrm{MnSO}_{4} \cdot 6 \mathrm{H}_{2} \mathrm{O}\end{array}$ & $34 \mathrm{~g} / \mathrm{L}$ \\
\hline
\end{tabular}

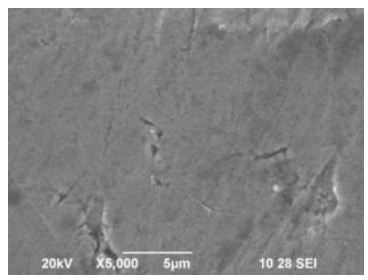

Figure 2. SEM Micrograph of uncoated at magnification of X5000, $5 \mu \mathrm{m}$

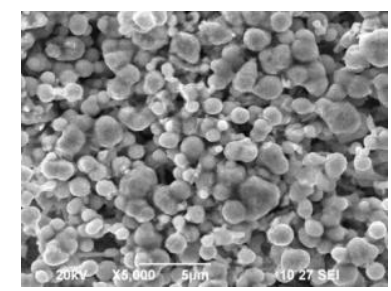

Figure 3. SEM Micrograph of the $\mathrm{Ni}+\mathrm{Zn}$ coated surface at magnification of $\mathrm{X5000,5} \mu \mathrm{m}$ 


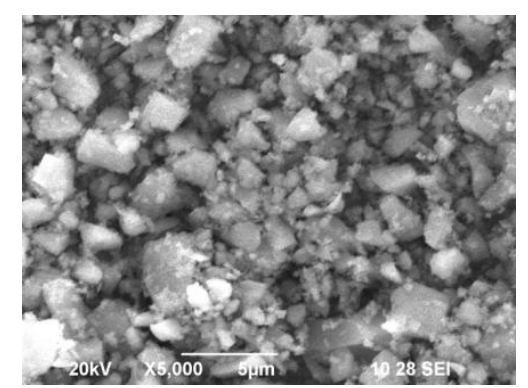

Figure 4. SEM Micrograph of the Ni+Mn coated surface at magnification of X5000, $5 \mu \mathrm{m}$

Fig. 3 SEM micrograph explains the distribution of $\mathrm{Ni}$ and $\mathrm{Zn}$ particles on the surface of base material. $\mathrm{Ni}$ and $\mathrm{Zn}$ particles are spread over the base surface giving the impression of another layer like structure. Comparing to the uncoated surface of the base substrate, the $\mathrm{Ni}$ and $\mathrm{Zn}$ particles,found evenly distributed on the surface, improve the micro hardness and wear resistivity. Fig. 4 SEM micrograph explains the distribution of $\mathrm{Ni}$ and $\mathrm{Mn}$ particles on the surface of base material. $\mathrm{Ni}$ and $\mathrm{Mn}$ particles are evenly spread over the base surface giving the impression of another layer like structure.This distributionon the surface, improve the micro hardness and wear resistivity.

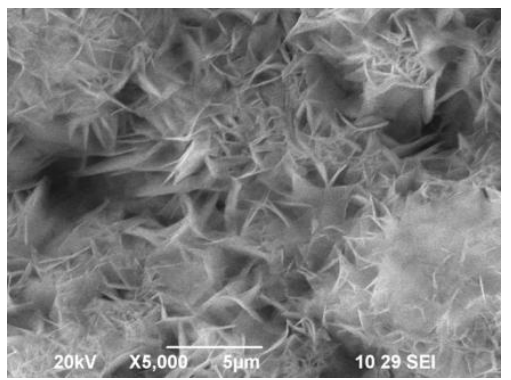

Figure 5. SEM Micrograph of the $\mathrm{Zn}+\mathrm{Mn}$ coated surface at magnification of $\mathrm{X5000,5} \mu \mathrm{m}$

Fig. 5 SEM micrograph explains the distribution of $\mathrm{Zn}$ and $\mathrm{Mn}$ particles on the surface of base material. Comparing to the uncoated surface of the base substrate, the $\mathrm{Zn}$ and $\mathrm{Mn}$ particles are evenly distributed on the surfaceings.

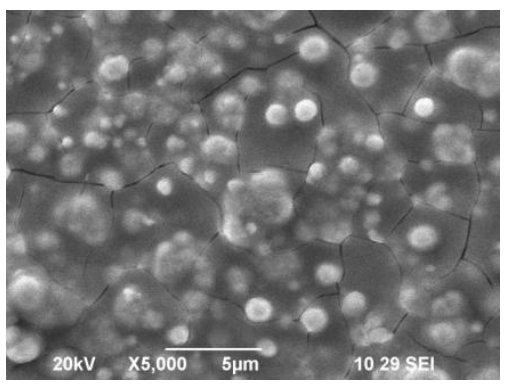

Figure 6. SEM Micrograph of the $\mathrm{Ni}+\mathrm{Zn}+\mathrm{Mn}$ coated surface at magnification of X5000, $5 \mu \mathrm{m}$

Fig. 6 SEM micrograph explains the distribution of $\mathrm{Ni}, \mathrm{Zn}$ and $\mathrm{Mn}$ particles on the surface of base material. $\mathrm{Ni}, \mathrm{Zn}$ and Mn particles are spread over the base surface producing a frame work of a number of cotton balls spread densely on the surface. Comparing to the uncoated surface of the base substrate, the $\mathrm{Ni}, \mathrm{Zn}$ and $\mathrm{Mn}$ particles are evenly distributed on the surface and less wear resistivity than the $\mathrm{Ni}$ and $\mathrm{Mn}$ coating which having very less wear of $19 \mu \mathrm{m}$ was recorded in the experiment.

B. Elemental compositions of coated composites study using energy dispersive $X$-ray diffraction (EDS)

The elemental composition of the specimens was studied using EDS analyses and the results show that the corresponding peaks to confirm the presence of elements like $\mathrm{Ni}, \mathrm{Mn}$ and $\mathrm{Zn}$ in the specimen. In all the samples, theoretical values are correlated with the experimental results.

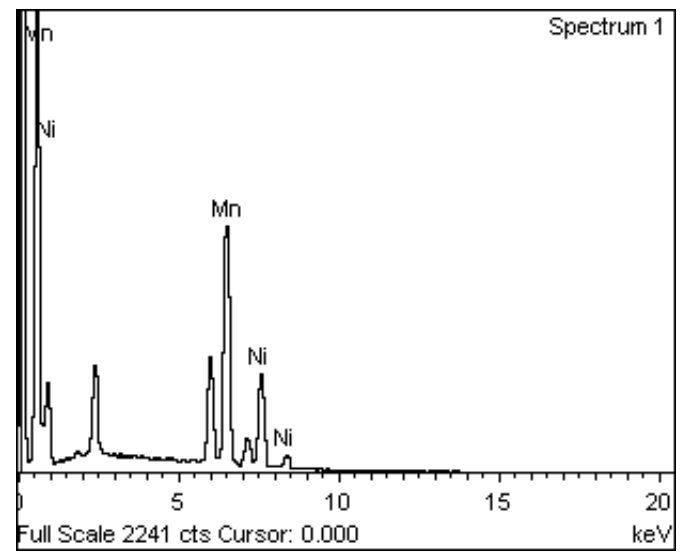

Figure 7. EDX result for $\mathrm{Ni}+\mathrm{Mn}$ coated substrate

TABLE VI. Ni and Mn elemental composition

\begin{tabular}{|l|l|l|l|l|l|}
\hline Element & $\begin{array}{l}\text { App. } \\
\text { Conc. }\end{array}$ & $\begin{array}{l}\text { Intensity } \\
\text { Corrn. }\end{array}$ & $\begin{array}{l}\text { Weight } \\
\%\end{array}$ & $\begin{array}{l}\text { Weight \% } \\
\text { Sigma }\end{array}$ & $\begin{array}{l}\text { Atomic } \\
\%\end{array}$ \\
\hline Mn K & 15.87 & 1.0452 & 41.90 & 1.21 & 43.53 \\
\hline Ni K & 20.21 & 0.9599 & 58.10 & 1.21 & 56.47 \\
\hline Totals & & & 100.00 & & \\
\hline
\end{tabular}

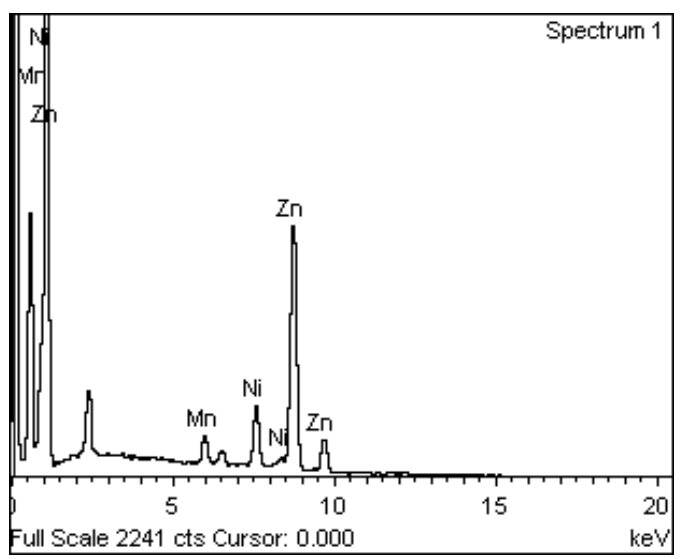

Figure 8. EDX result for $\mathrm{Ni}+\mathrm{Zn}+\mathrm{Mn}$ coated substrate

TABLE VII. Ni, Zn and Mn elemental composition

\begin{tabular}{|l|l|l|l|l|l|}
\hline Element & $\begin{array}{l}\text { App. } \\
\text { Conc. }\end{array}$ & $\begin{array}{l}\text { Intensity } \\
\text { Corrn. }\end{array}$ & $\begin{array}{l}\text { Weight } \\
\%\end{array}$ & $\begin{array}{l}\text { Weight } \\
\% \text { Sigma }\end{array}$ & $\begin{array}{l}\text { Atomic } \\
\%\end{array}$ \\
\hline Mn K & 3.52 & 1.0688 & 5.51 & 0.45 & 5.99 \\
\hline Ni K & 9.29 & 1.2589 & 11.55 & 0.70 & 12.57 \\
\hline Zn K & 51.93 & 0.9752 & 83.31 & 0.81 & 81.44 \\
\hline Total & & & 100.00 & & \\
\hline
\end{tabular}




\section{ELECTRODEPOSITION OF TRANSITION METAL COMPOSITES ON MILD STEEL: STRUCTURAL AND WEAR BEHAVIOUR}

\section{X-ray diffraction Characterization}

In order to understand the structural properties of the specimens XRD were performed with $\mathrm{CuK} \alpha$ wavelength and scanning in the ranges from 10 to 90 degree. The sharp and well defined Bragg peaks indicate that the coated materials are in crystalline in nature. All the observed diffraction peaks are corresponds to the formation of metal coating on the surface of the specimen.

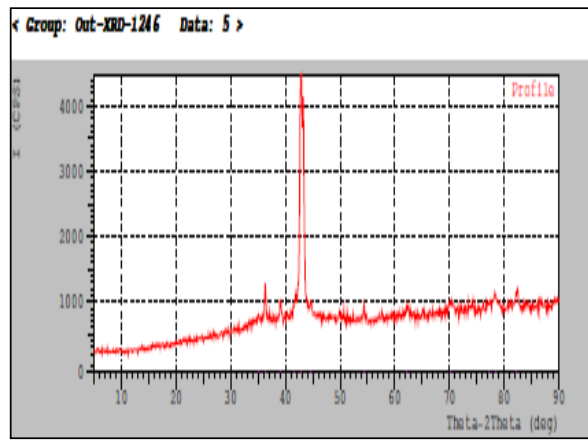

Figure 9. Indication of coated materials are in crystalline in nature

\section{Hardness test result}

Table 8 shows that hardness value of $\mathrm{Ni}+\mathrm{Mn}$ coated sample havehigh hardness value of $77.25 \mathrm{HRB}$ than the uncoatedsample, and $\mathrm{Ni}+\mathrm{Zn}+\mathrm{Mn}$ composition.

TABLE VIII. Hardness value

\begin{tabular}{|l|l|l|}
\hline S.No & Material & $\begin{array}{l}\text { Hardness value } \\
\text { (HRB) }\end{array}$ \\
\hline 1. & $\begin{array}{l}\text { Uncoated } \\
\text { sample }\end{array}$ & 65 \\
\hline 2. & $\mathrm{Ni}$ & 75 \\
\hline 3. & $\mathrm{Ni}+\mathrm{Zn}$ & 71.75 \\
\hline 4. & $\mathrm{Ni}+\mathrm{Mn}$ & 77.25 \\
\hline 5. & $\mathrm{Zn}+\mathrm{Mn}$ & 72.5 \\
\hline 6. & $\mathrm{Ni}+\mathrm{Zn}+\mathrm{Mn}$ & 75.3 \\
\hline
\end{tabular}

\section{E. Wear results}

Pin-on-disc test was utilized to observe the tribological properties of the substrate. The experiment was as per ASTM G99-95 standards at the speed of $300 \mathrm{rpm}$ for 6 minutes under a load of $10 \mathrm{~N}$. Using acetone the disc was cleaned before conducting the test. The substrates wear, coefficient of friction and frictional force are given in fig. 10 to 15. In this regard, the aim of this work is to find the important combination of factors influencing the process to achieve the minimum wear and co-efficient of friction.

The wear test, the graph represents the amount of wear (y axis) with respect to increasing time (x axis). From the Fig. 10 to 15 , the wear rate is directly proportional to the time i.e., when the time is increase, the wear rate of the uncoated and coated substrates also increase. For the composite coated substrate, the result gave the less wear compared to the uncoated substrate. From the table 9 weight variation of before and after the wear test of $\mathrm{Ni}, \mathrm{Ni}+\mathrm{Zn}, \mathrm{Ni}+\mathrm{Mn}$, $\mathrm{Zn}+\mathrm{Mn}, \mathrm{Ni}+\mathrm{Zn}+\mathrm{Mn}$ coated substrates to find the wear loss as $0.01 \mathrm{~g}, 0.02 \mathrm{~g}, 0.01 \mathrm{~g}, 0.007 \mathrm{~g}, 0.01 \mathrm{~g}$ with respectively.

\section{TABLE IX. Data of wear loss of composites coated samples}

\begin{tabular}{|l|l|l|l|}
\hline \multirow{2}{*}{ S.No } & \multirow{2}{*}{ Samples } & \multicolumn{2}{|l|}{ Weight $(\mathrm{g})$} \\
\cline { 3 - 4 } & & $\begin{array}{l}\text { Before } \\
\text { test }\end{array}$ & $\begin{array}{l}\text { After } \\
\text { test }\end{array}$ \\
\hline 1. & $\mathrm{Ni}$ & 19.450 & 19.440 \\
\hline 2. & $\mathrm{Ni}+\mathrm{Zn}$ & 19.620 & 19.600 \\
\hline 3. & $\mathrm{Ni}+\mathrm{Mn}$ & 19.290 & 19.280 \\
\hline 4. & $\mathrm{Zn}+\mathrm{Mn}$ & 20.120 & 20.113 \\
\hline 5. & $\mathrm{Ni}+\mathrm{Zn}+\mathrm{Mn}$ & 19.390 & 19.380 \\
\hline
\end{tabular}

Uncoated sample's wear, coefficient of friction and frictional force for 6 minutes are shown in Fig 10. It is inferred that, when the time was increasing, the amount wear also increased up to $49 \mu \mathrm{m}$. Nickel coated sample's wear, coefficient of friction and frictional force for 6 minutes are shown in Fig. 11. The graph represents, the amounts wear increasing up to $22 \mu \mathrm{m}$ at first 260 seconds. Then afterwards with time increasing, wear hikes to $34 \mu \mathrm{m}$. The coefficient of friction gradually decreased from 0.8 to 0.55 and frictional force maintained at $5.8 \mathrm{~N}$.

Nickel and zinc coated sample's wear, coefficient of friction and frictional force with respect to 6 minutes are presented in Fig 12. The graph represents, the amounts wear increasing up to $40 \mu \mathrm{m}$ at first 180 seconds. Then afterwards on increasing time, wear hikes into $45 \mu \mathrm{m}$. The coefficient of friction gradually decreased from 0.75 to 0.5 and frictional force maintained at $5.5 \mathrm{~N}$.

Nickel and manganese coated sample's wear, coefficient of friction and frictional force for 6 minutes are shown in Fig. 13. The graph represents, the amount of wear increasing up to $12 \mu \mathrm{m}$ at first 180 seconds. Then after the time increasing, wear hikes into $19 \mu \mathrm{m}$. Coefficient of friction gradually decreased from 0.55 to 0.5 and frictional force remained at $5.5 \mathrm{~N}$. It is having more wear resistance than other coatings.

Zinc and manganese coated sample's wear, coefficient of friction and frictional force with respect to 6 minutes as shown in Fig. 14. The graph represents, the amounts wear increasing up to $30 \mu \mathrm{m}$ at first 180 seconds. Then after the time increasing, wear hikes into $38 \mu \mathrm{m}$. Coefficient of friction gradually decreased from 0.8 to 0.6 and frictional force also decreased from $8 \mathrm{~N}$ to $6 \mathrm{~N}$.

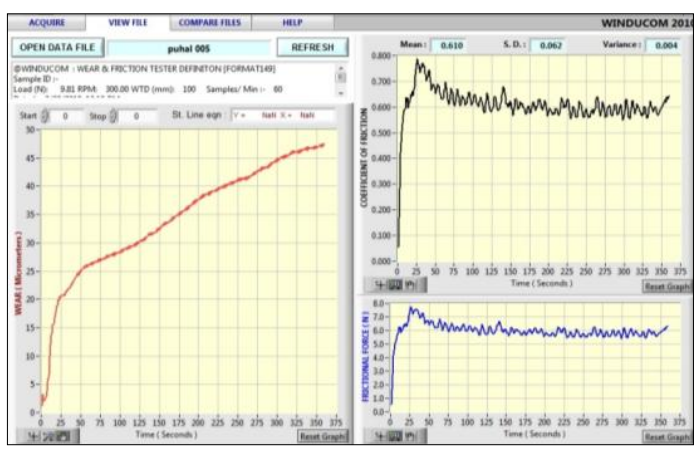

Figure 10. Wear, coefficient of friction and frictional force for the uncoated sample 


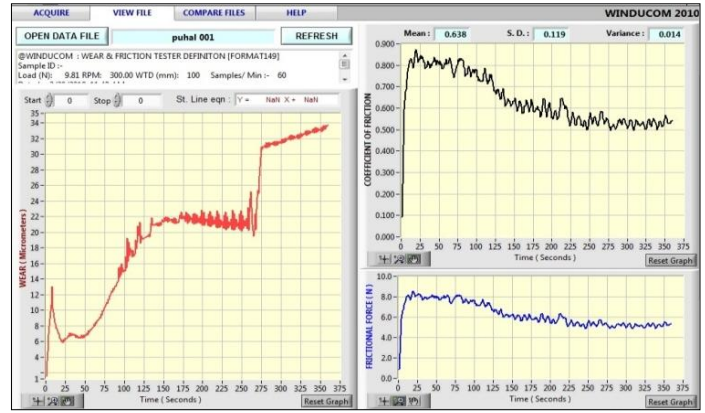

Figure 11. Wear, friction coefficient and frictional force for pure Ni coated sample

Nickel, zinc and manganese coated sample's wear, coefficient of friction and frictional force are shown in Fig. 15. The graph represents, the amounts wear increasing up to $35 \mu \mathrm{m}$ at first 180 seconds. Then after the time increasing, due to the resistance layer formation, wear was maintained at $36 \mu \mathrm{m}$. Coefficient of friction gradually decreased from 0.8 to 0.5 and frictional force also decreased from $8 \mathrm{~N}$ to 5 $\mathrm{N}$.

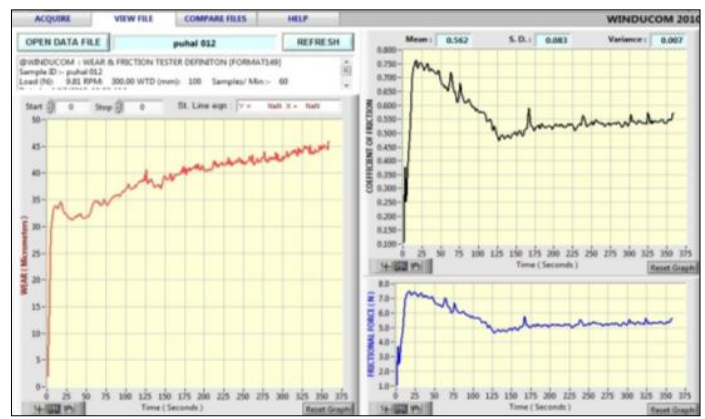

Figure 12. Wear, coefficient of friction and frictional force for $\mathrm{Ni}+\mathrm{Zn}$ coated sample

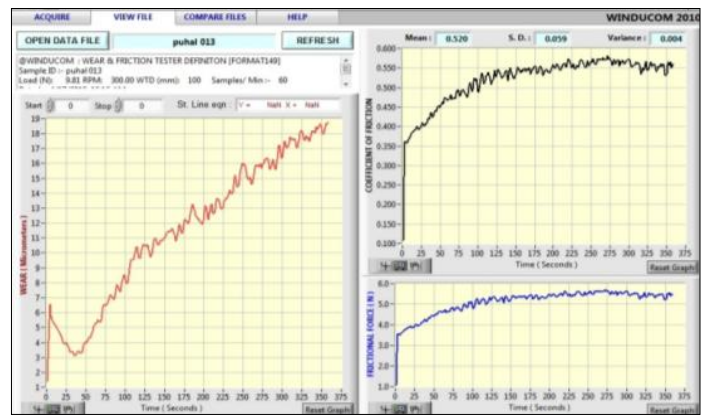

Figure 13. Wear, friction coefficient and frictional force for $\mathrm{Ni}+\mathrm{Mn}$ coated samples

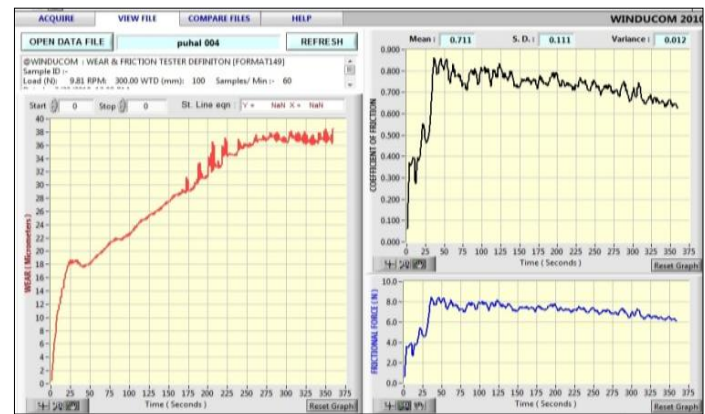

Figure 14. Wear, friction coefficient and frictional force for $\mathrm{Zn}+\mathrm{Mn}$ coated samples

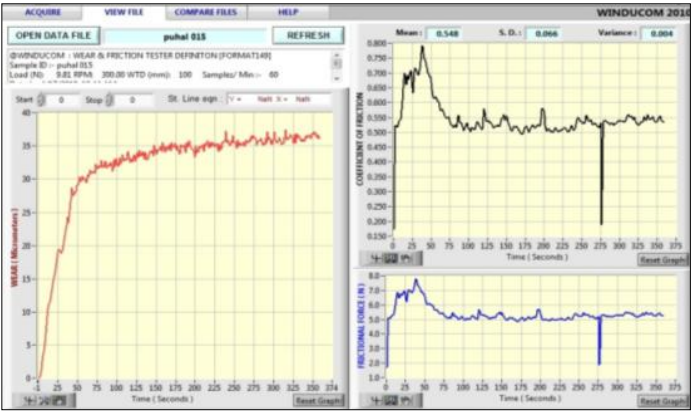

Figure 15. Wear, friction coefficient and frictional force for $\mathbf{N i}+\mathbf{Z n}+\mathrm{Mn}$ coated samples

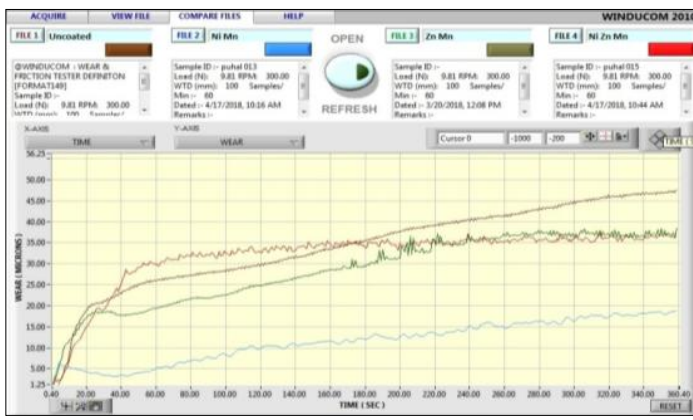

Figure 16. Comparison of frictional wear among uncoated, $\mathrm{Ni}+\mathrm{Mn}, \mathrm{Zn}+\mathrm{Mn}$ and $\mathrm{Ni}+\mathrm{Zn}+\mathrm{Mn}$ coated samples

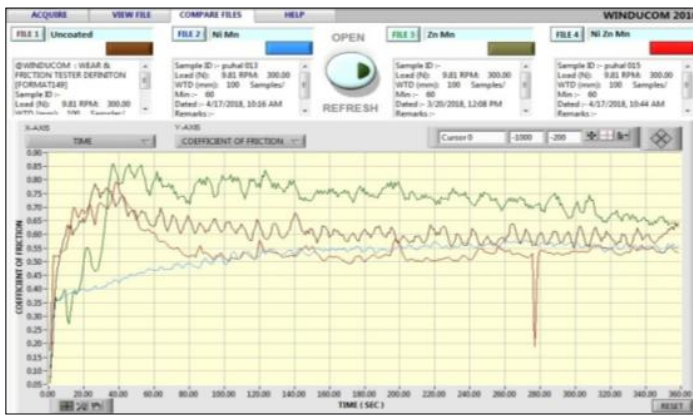

Figure 17. Comparison of coefficient of friction among uncoated, $\mathrm{Ni}+\mathrm{Mn}, \mathrm{Zn}+\mathrm{Mn}$ and $\mathrm{Ni}+\mathrm{Zn}+\mathrm{Mn}$ coated samples

Fig. 16 represents the comparison of wear among uncoated, $\mathrm{Ni}+\mathrm{Mn}, \mathrm{Zn}+\mathrm{Mn}$ and $\mathrm{Ni}+\mathrm{Zn}+\mathrm{Mn}$ coated samples. From that, $\mathrm{Ni}+\mathrm{Mn}$ and $\mathrm{Ni}+\mathrm{Zn}+\mathrm{Mn}$ coated samples having high wear resistance than the remaining uncoated, $\mathrm{Zn}+\mathrm{Mn}$ composite coated samples.

Fig. 17 represents the comparison of coefficient friction among uncoated, $\mathrm{Ni}+\mathrm{Mn}, \mathrm{Zn}+\mathrm{Mn}$ and $\mathrm{Ni}+\mathrm{Zn}+\mathrm{Mn}$ coated samples. From that, $\mathrm{Ni}+\mathrm{Mn}$ and $\mathrm{Ni}+\mathrm{Zn}+\mathrm{Mn}$ coated samples having less coefficient of friction by comparing with remaining uncoated and $\mathrm{Zn}+\mathrm{Mn}$ composite coated samples, which having a high coefficient of friction.

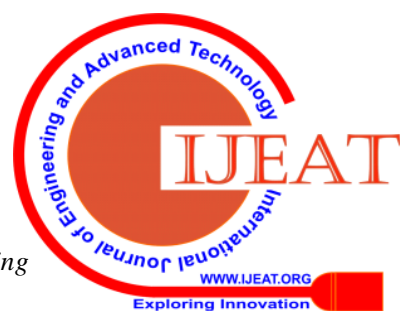




\section{ELECTRODEPOSITION OF TRANSITION METAL COMPOSITES ON MILD STEEL: STRUCTURAL AND WEAR BEHAVIOUR}

\section{CONCLUSION}

Composite coatings were carried out on mild steel by using electrodeposition technique. SEM micrograph shows even distribution of $\mathrm{Ni}, \mathrm{Zn}$ and $\mathrm{Mn}$ particles on the surface of the base material. EDX analysis shows that the corresponding peaks to confirm the presence of elements like $\mathrm{Ni}, \mathrm{Mn}$ and $\mathrm{Zn}$ in the specimens. XRD studies reveal that, the sharp and well defined Bragg peaks indicate that the coated materials are in crystalline in nature. From the hardness test, compared with uncoated sample, $\mathrm{Ni}+\mathrm{Mn}$ and $\mathrm{Ni}+\mathrm{Zn}+\mathrm{Mn}$ coated samples having the high hardness value. Thus, the composite coated sample's hardness was improved.

Wear characteristics of the composite coated mild steel are investigated. All the coated samples had better wear resistance. On both coated and uncoated substrates, tribological test was conducted. From the wear test results, comparing with uncoated sample, $\mathrm{Ni}, \mathrm{Zn}$ and $\mathrm{Mn}$ coating had less wear resistivity than the Ni and Mn coating, which having very less amount wear was recorded in the experiment. Thus the coated sample proved that, it has improved wear resistance. This enhancement is due to the $\mathrm{Ni}+\mathrm{Mn}$ and $\mathrm{Ni}+\mathrm{Zn}+\mathrm{Mn}$ composite coatings on the mild steel and the evidenced better wear resistance shown in the wear test result.

\section{ACKNOWLEDGEMENT}

The authors acknowledge the facilities provided at Kumaraguru College of Technology for preparing and testing the specimens.

\section{REFERENCES}

1. Holmberg, Kenneth, Peter Andersson, and Ali Erdemir. "Global energy consumption due to friction in passenger cars." Tribology International 47 (2012): 221-234.[a]

2. Sathyabalan P, Kumar RS and Balasubramanian S, "Prediction of tensile strength and elongation in hybrid aluminium composite using ANN", International Journal of Civil Engineering and Technology, vol. 8, issue 9, pp. 249254, 2017. [b]

3. Valmik Bhavar, Prakash Kattire, Sandeep Thakare, Sachin Patil and Singh RKP, "A Review on Functionally Gradient Materials (FGMs) and Their Applications", IOP Conf. Series: Materials Science and Engineering, 229 (2017) 012021.

4. Balasubramanian S, Muthukumaran V and Sathyabalan P, "A Study on the Effect of Process Parameters of Laser Hardening in Carbon Steels",International Journal of Civil Engineering and Technology (IJCIET) Volume 8, Issue 9, (2017), pp. 201207.

5. Farhat, Zoheir N. "Wear resistant composite coatings." Materials Characterization 60, no. 4 (2009): 337 345.

6. Tsai, T. K., S. J. Hsueh, J. H. Lee, and J. S. Fang. "Optical properties and durability of $\mathrm{Al}_{2} \mathrm{O}_{3}-\mathrm{NiP} / \mathrm{Al}$ solar absorbers prepared by electroless nickel composite plating." Journal of electronic materials 41, no. 1 (2012): 53-59

7. Kanagalasara, Vathsala, and Thimmappa Venkatarangaiah Venkatesha. "Studies on electrodeposition of $\mathrm{Zn}-\mathrm{MoS}_{2}$ nanocomposite coatings on mild steel and its properties." Journal of Solid State Electrochemistry 16, no. 3 (2012): 993-1001.

8. Kannan, R., Devaki, P., Premkumar, P. S., \& Selvambikai, M. "Effect of tungsten (W) on structural and magnetic properties of electroplated NiFe thin films for MEMS applications" Materials Research Express, 5(4),(2018): 046414.

9. Qin, Liyuan, Jiying Xu, Jianshe Lian, Zhonghao Jiang, and Qing Jiang. "A novel electrodeposited nanostructured $\mathrm{Ni}$ coating with grain size gradient distribution." Surface and Coatings Technology 203, no. 1-2 (2008): 142-147.

10. Tsurtsumia, Gigla, David Gogoli, Nana Koiava, Izolda Kakhniashvili, Nunu Jokhadze, Tinatin Lezhava, Nikoloz Nioradze, and Dimitri Tatishvili. "Electrodeposition and Characterization of $\mathrm{Mn}-\mathrm{Cu}-\mathrm{Zn}$ Alloys for Corrosion Protection Coating." In IOP Conference Series: Earth and Environmental Science, vol. 95, no. 4, p. 042035. IOP Publishing, 2017.

11. Kanani, Nasser, "Electroplating: Basic Principles, Processes and Practice",Elsevier, 2004.

12. El-Sherik, A. M., and U. Erb. "Synthesis of bulk nanocrystalline nickel by pulsed electrodeposition." Journal of Materials Science 30, no. 22 (1995): 5743-5749.

13. Shen, Y. F., W. Y. Xue, Y. D. Wang, Z. Y. Liu, and L. Zuo. "Mechanical properties of nanocrystalline nickel films deposited by pulse plating." Surface and Coatings Technology 202, no. 21 (2008): 5140-5145.

14. Huang, Xinlong, Ying Xiong, Longhua Liu, Yangchao Tian, and Gang Liu. "Investigation on nickel/alumina-nanoparticles co-deposition." Microsystem technologies 15, no. 5 (2009) 723-729.

15. Wu, Bin, Bin-shi Xu, Bin Zhang, and Shi-yun Dong. "The effects of parameters on the mechanical properties of $\mathrm{Ni}$ based coatings prepared by automatic brush plating technology." Surface and Coatings Technology 201, no. 12 (2007): 5758-5765.

16. Amuda, Muhammed Olawale Hakeem, Subair, W., and Obitayo, O. W. "Study of Optimum Conditions for Zinc Plating on Mild Steel." International Journal of Engineering Research in Africa, vol. 2, pp. 31-39. Trans Tech Publications, 2010. 